\title{
THERMAL BEHAVIOR OF FOREST BIOMASS WASTES PRODUCED DURING COMBUSTION IN A BOILER SYSTEM
}

\author{
Reny Aldo Henne ${ }^{2} \odot$, Martha Andreia Brand ${ }^{3 *} \odot$, Bianca Schveitzer ${ }^{4}$ and Viviane Aparecida Spinelli \\ Schein $^{5}$.
}

\footnotetext{
${ }^{1}$ Received on 29.11.2018 accepted for publication on 30.04.2019.

${ }^{2}$ Centro Universitário Unifacvest, Lages, SC- Brasil. E-mail: <renyhenne@hotmail.com>.

${ }^{3}$ Universidade do Estado de Santa Catarina, Departamento de Engenharia Florestal ,Florianópolis, SC- Brasil. E-mail: $<$ martha.brand@udesc.br $>$.

${ }^{4}$ Empresa de Pesquisa Agropecuária e Extensão Rural de Santa Catarina, Caçador, SC- Brasil. E-mail: <biancaschveitzer@udesc.br>.

${ }^{5}$ Universidade do Estado de Santa Catarina, Departamento de Ambiental e Sanitária ,Florianópolis, SC- Brasil. E-mail:<viviane.schein@udesc.br>.

*Corresponding author.
}

\begin{abstract}
It is known that during the biomass combustion in industrial systems the formation of residues containing ashes and residual carbon occurs. The content of the residues varies according to the efficiency and operating parameters of the combustion chambers. The characterization of these residues is an essential tool to identify their potential for energy reuse. The aim of this paper was to analyze the thermal behavior of the biomass and the residues yielded during the combustion process in a boiler system. For this purpose, forest biomass and ash samples have been analyzed in a laboratory and at four collection points of generation and treatment of the combustion residues (readler, hopper, scrubber, and decanter) inside the boiler of a power plant. The thermogravimetric analysis (TGA and DTA) have been carried out on all samples. Moreover, the ultimate analysis, the proximate analysis and the gross calorific value of all samples have been determined. Results show that the biomass burning efficiency in the boiler furnace was high, which was proven by the chemical composition and thermal degradation behavior of the residues collected in the readler. The scrubber's light wastes presented chemical and energy properties $(7180 \mathrm{kcal} / \mathrm{kg}, 75 \%$ fixed carbon content, $21 \%$ volatile content and $3.72 \%$ ash content), and thermal behavior similar to the ones found in the literature for eucalyptus charcoal. However, in order to reuse these combustion residues on reinjection or reheat systems, machine adjustments are essential to achieve burning efficiency and avoid operational problems. The decanter wastes did not show potential for energy reuse.
\end{abstract}

Keywords: Combustion efficiency; Reuse of ash; Thermogravimetric analysis.

\section{COMPORTAMENTO TÉRMICO DOS RESÍDUOS PRODUZIDOS NA COMBUSTÃO DA BIOMASSA FLORESTAL EM CALDEIRA}

RESUMO - Durante a queima da biomassa em sistemas industriais haverá a formação de resíduos contendo cinzas e carbono residual, cujo teor será variável em função da eficiência e dos parâmetros de operação das câmaras de combustão. A caracterização destes resíduos é ferramenta essencial para visualizar a sua potencialidade de reuso energético. Assim, o objetivo deste trabalho foi analisar o comportamento térmico da biomassa e dos resíduos gerados no processo de combustão em caldeira. Foram analisadas amostras de biomassa florestal e das cinzas geradas na combustão desta biomassa em laboratório, e em quatro pontos de geração e tratamento dos resíduos da combustão (readler, tremonha, lavador de gases e decantador) dentro da caldeira de uma termelétrica. Em todas as amostras foi realizada a análise termogravimétrica (TG e DTG) e determinadas a composição química elementar, análise imediata e o poder calorífico superior. A eficiência de queima da biomassa na fornalha da caldeira foi alta, demonstrada pela composição química e comportamento de degradação térmica dos resíduos coletados no readler. Os resíduos leves do lavador de gases apresentaram propriedades químicas e energéticas $(7180 \mathrm{kcal} / \mathrm{kg} ; 75 \%$ de teor de carbono fixo; $21 \%$ de teor de voláteis e 3,72\% de cinzas) e comportamento térmico similares ao observado para o carvão vegetal de eucalipto. Porém, para o reuso dos resíduos da combustão em caldeira, em sistemas de reinjeção ou requeima, ajustes nos equipamentos são essenciais para se alcançar a eficiência na queima e evitar problemas operacionais. Já os resíduos do decantador não apresentam potencial para reuso energético.

Palavras-Chave: Eficiência de combustão; Reuso de cinzas; Análise termogravimétrica.

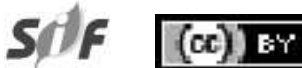

Revista Árvore 2019;43(1):e430108 http://dx.doi.org/10.1590/1806-90882019000100008 


\section{INTRODUCTION}

The purpose of biomass combustion for energy generation of energy is to release the energy of the chemical bonds of the fuel, and the minimum of organic carbon must preferably remain in the burning residues. The renewable energy system, from the removal of forest fuels to the final disposal of the ashes, should be operated as efficiently as possible to reduce anthropogenic emissions of greenhouse gases, and to enable a sustainable system of nutrient recycling (Sarenbo, 2009).

Biomass fuels differ from conventional fossil fuels used in combustion processes in many aspects. They generally have high moisture content, lower calorific value, a variety of smaller constituent parts such as chlorine, sulfur, phosphorus, nitrogen, and a variety of ash-forming metals. The design of the combustion devices and the choice of operational parameters are highly dependent on the properties of the biomass used.

The physical, chemical and energetic properties of this biofuel require the overcoming of several challenges such as the bed or grate sintering, defluidization, corrosion on the furnace wall, air dispatching, inlay and corrosion of the super-heater, incrustations, acid formation at the dew point, hygroscopic salts, and atmospheric emissions. These challenges are often linked to the chemistry of components and impurities of the fuels that make up the biomass ashes (Hupa et al., 2017).

Among these properties, the elemental analysis is one of the most important factors when studying biomass fuels. The amount of $\mathrm{N}, \mathrm{S}$, and $\mathrm{Cl}$ indicate the environmental impact of the use of the biofuel (Saidur et al., 2011). In addition, the percentages of C, H, and $\mathrm{O}$ can be used to estimate the biofuel's calorific value (Abbasi and Abbasi, 2010). The calorific value, in turn, is the energy property that expresses the amount of energy available in the fuel, and the gross calorific value (GCV) is defined as the amount of total heat (thermal energy) that is released during the complete combustion of a fuel's mass unit or volume unit, considering the formation of liquid water in products ( $\mathrm{kcal} / \mathrm{kg}$ or $\mathrm{kJ} / \mathrm{kg}, \mathrm{kcal} / \mathrm{m}^{3}$ or $\mathrm{kJ} / \mathrm{m}^{3}$ ) (Brand, 2010).

The proximate chemical analysis evaluates the percentage of volatile matter, fixed carbon and ash content of the biomass. This analysis is essential to study the behavior of the fuel at each stage of combustion. The high volatility of the biomass makes it a better fuel to be used as a raw material for combustion because fuels with higher volatile content burn faster than those with higher fixed carbon content (Saidur et al., 2011).

The ash content of different biomass sources varies, it can be as low as $0.5 \%$ on a dry-basis for some timber species or up to $20 \%$ for some grains, and agricultural/forest residues, particularly if they are contaminated with inert materials such as small stones, sand, and earth (Garba et al., 2013).

During the burning of biomass in industrial systems, there is the formation of residues containing ashes and residual carbon. The content of these residues varies according to the efficiency and the operating parameters of the combustion chambers. Therefore, the residual carbon content can be used to estimate the efficiency of the burning process and the potential for ash re-use. The more carbon is converted into energy, the greater is the efficiency and the lower is the volume of waste generated (James et al., 2012).

The need for a more critical analysis of the carbon, which was not burned, present in the waste and effective ways of capturing this energy as fuel need to be investigated, though. Furthermore, the carbon content in the ashes varies according to processing conditions, types of combustion equipment, and fuel source. Therefore, the residual carbon allows the exploitation of the residues as fuel (James et al., 2012).

In addition to the chemical and energetic properties of the biomass, and the residues generated during the burning process, the mass loss analysis is an important tool for the qualification of different types of fuels. This evaluation is done by means of the thermogravimetric analysis (TGA), which is used to assess the mass variation of a sample as a result of physical (sublimation, evaporation, condensation) or chemical (degradation, decomposition, oxidation) transformation as a function of time or temperature. In other words, it can be defined as a continuous process which measures the mass variation of a substance or material as a function of temperature and/or time (Mothé and Azevedo, 2002).

Revista Árvore 2019;43(1):e430108 
Thermogravimetry is a technique widely used to characterize the degradation profile of polymers and other materials. Exposure to high temperatures can sometimes modify the chemical structure, and consequently the physical properties of materials. Therefore, the thermal degradation curve, under nonisothermal conditions, shows the profile of the thermal resistance or stability that the material presents when subjected to a temperature scan (Mothé and Azevedo, 2002).

TGA is an alternative that can be applied in the determination of the energy performance of biomass fuels (Barneto et al., 2008). The comprehensive knowledge of volatilization kinetics during pyrolysis can facilitate the development (planning and design) and the operation of power plants (Félix et al., 2017).

Nevertheless, by analyzing the chemical and energetic properties along with the thermal degradation behavior of both the biomass and the waste generated during the combustion process, it is possible to evaluate the efficiency of this biofuel's burning system. Moreover, the ash characterization is an essential tool to identify the potential use of these residues for re-burning in order to take advantage of the residual carbon contained in them.

Thus, the aim of this study was to analyze the thermal behavior of the biomass and the residues generated during the combustion process in a boiler system.

\section{MATERIALS AND METHODS}

The study was carried out at a thermal power plant located in Lages, Santa Catarina, Brazil (2748'34.5'S $50^{\circ} 22^{\prime} 34.9$ ' W), which has a production capacity of $28 \mathrm{MW} /$ hour. The energy is produced through the burning of residual forest biomass from the timber industry of the surrounding region.

The power plant is equipped with a furnace, a boiler, a superheater, an economizer and an air heater. The furnace, which is the place where the forest biomass burns, is composed of 6 biomass feed points along the front wall of the furnace (Figure 1 (6)). At this point, the first sample, composed by the biomass used as fuel in the boiler, was collected and named "biomass". As the furnace is a fixed-grate type, the fuel is fed in the form of a layer of about 30 to $40 \mathrm{~cm}$ at the bottom of the boiler. The temperatures inside the furnace range from 800 to $1000^{\circ} \mathrm{C}$.

During the combustion process, the higher density residues (bottom ash) fall by gravity into the bottom of the furnace in a water seal and are extracted by a machine called Readler (Figure 1 (1)). The second sample, named "readler residues", was collected at this point. It was generated by the cleanings of the grates' sections and it is composed of ashes, nonpyrolyzed chips, and stones.

Lower density residues (fly ash) are drawn by the gases towards the superheaters located in the upper part of the furnace. After this point, the residues pass through the Hopper (Figure 1 (2)), where a sample of the dragged particles, named "hopper residues", was collected at the furnace exit.

After that, the wastes are led to the Pre-Air and Gas Scrubber (Figure 1 (3)) where they pass through a water seal and are directed to the rotating sieve (which separates the coarse particles from the fine particles). At this point, the sample named "scrubber residues" was collected. The fine particles are sent to the Decanter (Figure 1 (4)) which, in turn, pumps the fluid with the wastes to a scrub filter. At the scrub filter, a sample of ash with very fine particles and with a lower moisture content was obtained, this sample was named "decanter residues".

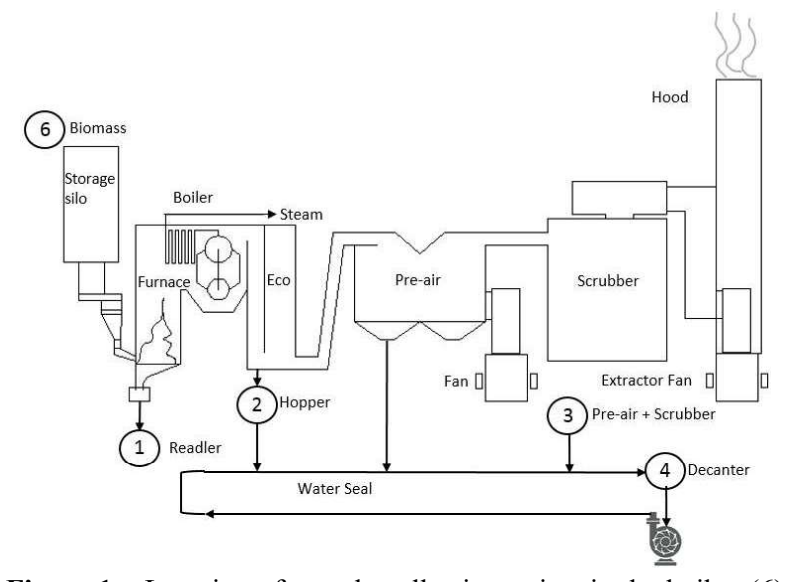

Figure 1 - Location of sample collection points in the boiler. (6) biomass feeding point; (1) Readler; (2) Hopper; (3) Scrubber; (4) Decanter.

Figura 1 - Pontos de coleta das amostras analisadas na caldeira. (6) Pontos de alimentação da biomassa na fornalha da caldeira; (1) Readler; (2) Tremonha; (3) Peneira rotativa do lavador de gases; (4) Decantador.

\section{Revista Árvore 2019;43(1):e430108}


Each sample consisted of $5 \mathrm{~kg}$ of biomass collected at each point. Part of the biomass sample collected at the furnace entrance was calcined in the laboratory to obtain the sample defined as "biomass ashes". Calcination was carried out in a muffle oven at a temperature of $1000^{\circ} \mathrm{C}$ for 3 hours, and 6 hours of cooling. The aim of this procedure was to enable the complete biomass combustion and obtain a material free or almost free of residual carbon, which allows the comparison of the values obtained from the ashes produced in the laboratory with the ones obtained from the residues of the combustion in the boiler.

The composition of the forest biomass entering the furnace is $70 \%$ chip, $25 \%$ sawdust, and $5 \%$ bark, logs, and top cuts. Regarding the species, $99.5 \%$ of the residues are from Pinus spp. trees and $0.5 \%$ Eucalyptus spp. trees. The biomass comes from sawmill wastes, and the average consumption is 58 tons per hour, with a moisture content of approximately $50 \%$.

The thermogravimetric analysis (TGA) of biomass, biomass ashes, and residues produced in the boiler (readler, hopper, scrubber, and decanter) have been performed to determine their thermal behavior. As a support for a better understanding of the behavior of the materials during controlled combustion, the elemental composition, the immediate composition and the gross calorific value (GCV) of the samples have also been determined.

A TGA 2000 (Automatic Multiple Sample Thermogravimetric Analyzer) thermogravimetric scale, brand NAVAS Instruments, has performed the thermogravimetric analysis. This equipment can run the analyses of 19 samples simultaneously. The test has been performed with atmospheric air, with a flow of $2.5 \mathrm{~L} / \mathrm{min}$ of air. The heating rate was $10^{\circ} \mathrm{C} / \mathrm{min}$, from room temperature to $1000^{\circ} \mathrm{C}$. The thermogravimetric curves (TG) for the mass loss as a function of temperature, and the first derivative curve (DTG) were then used to evaluate the rate of mass loss. Also, the DTG curve has been overlapped on the same graph, which represents the derivative of the first curve, that is, $\mathrm{dM} / \mathrm{dT}$, considering the peak's elimination temperature.

The elemental analysis has been performed on a PerkinElmer CHNS elemental analyzer, model 2400, based on the classical Pregl-Dumas method. The samples have been subjected to combustion in a pure oxygen environment, and the residual combustion gases have been measured in an automated way.

The proximate analysis has been carried out in a thermogravimetric scale, according to ASTM 1762 (ASTM, 2013), with a temperature of $9000 \mathrm{C}$ for the determination of the volatile content and $700 \mathrm{oC}$ for the ash content. The determination of the gross calorific value has been performed in triplicate, according to DIN 51900 (Din, 2003), in a calorimetric bomb, model IKA C2000.

For the chemical and energetic properties of the samples, the means and coefficient of variations have been obtained and submitted to the Scott Knott test at a 95\% probability level. Results have been analyzed through analysis of variance (ANOVA).

\section{RESULTS}

The analysis of the degradation of residual waste and biomass samples is a useful tool for determining the thermal properties of these materials. Through this analysis, it is possible to verify the behavior of the samples with the temperature variation, and the quantity of material (Figure 2) with the potential for conversion into thermal energy. Using the residues' energy in reinjection systems in the boiler where the waste is generated or reheated in another energy system.

From the data presented in the graphs (Figure 2), it was possible to extract the thermal degradation temperatures at each stage of mass loss (TG) of all the analyzed samples (Table 1).

For a better understanding of the mass loss behavior (TG) and the mass loss rate (DTG) of both biomass and residues, the elemental analysis, the proximate analysis, and the gross calorific value have been carried out, results are presented in Table 2 .

\section{DISCUSSION}

Nyakuma et al. (2016) divided the mass loss curves (TG) of the thermogravimetric analysis of empty palm fruit pellets into three main stages of thermal degradation: drying (Stage I), active pyrolysis (Stage II), and passive pyrolysis (Stage III).

By applying the same definitions, Figure 2 (a) can be divided as follows. Stage I (mass loss up to $150^{\circ} \mathrm{C}$ ), in which the volatilization of the constitution water 
(a)

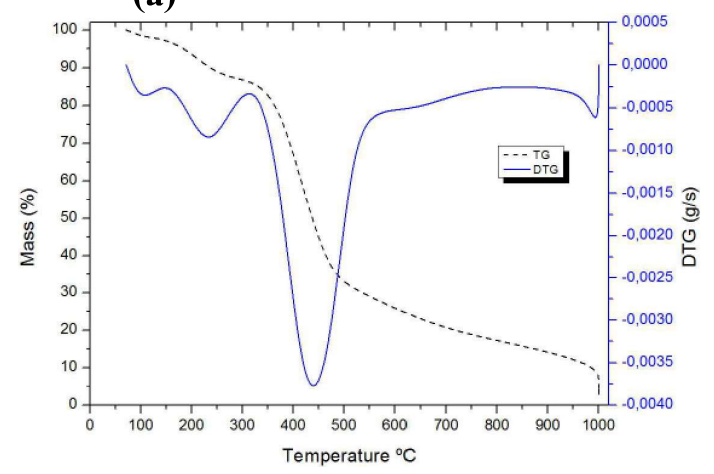

(c)

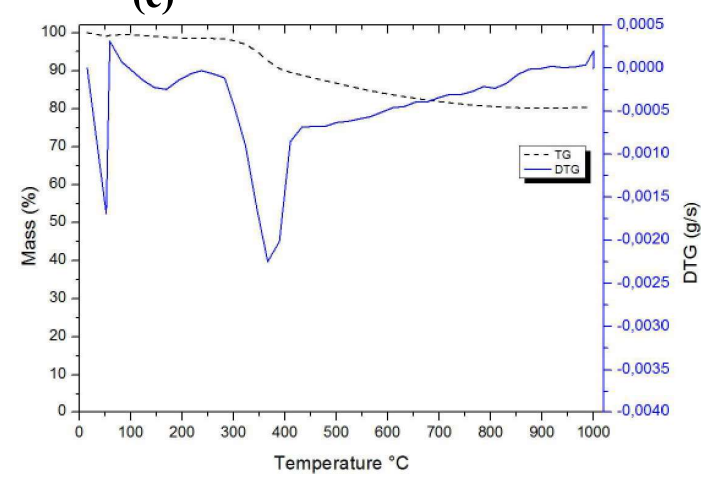

(e)

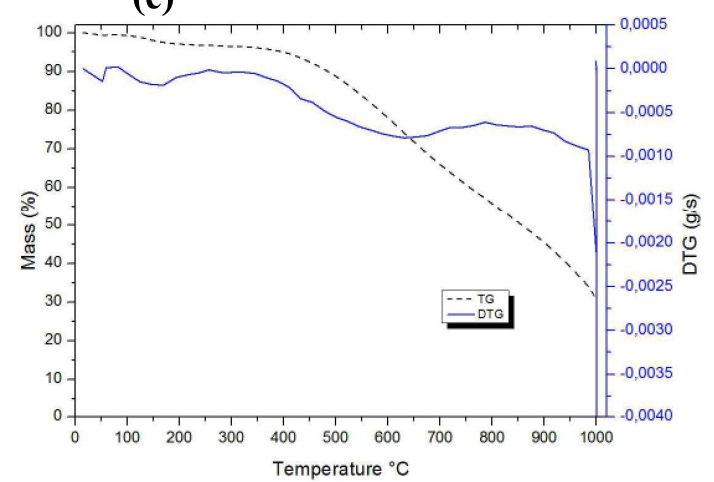

(b)

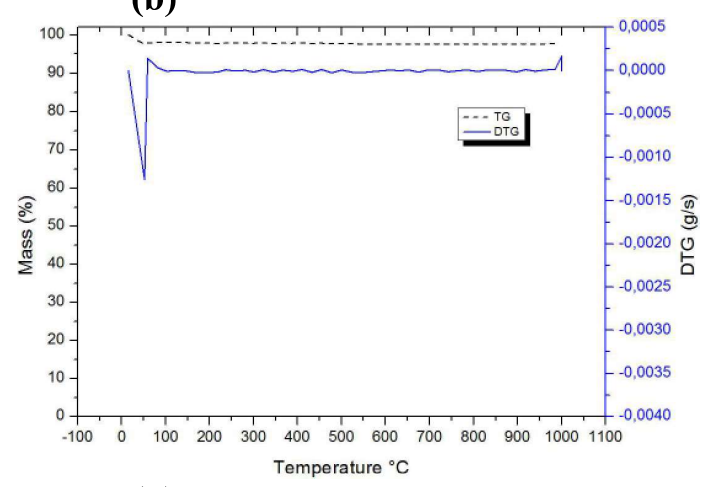

(d)

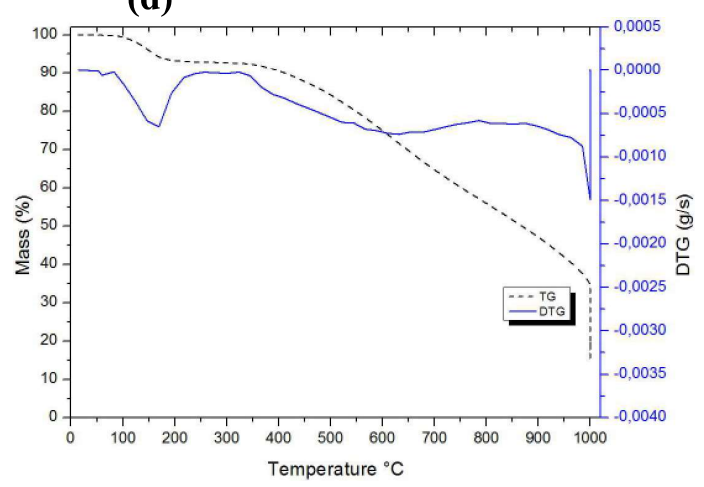

(f)

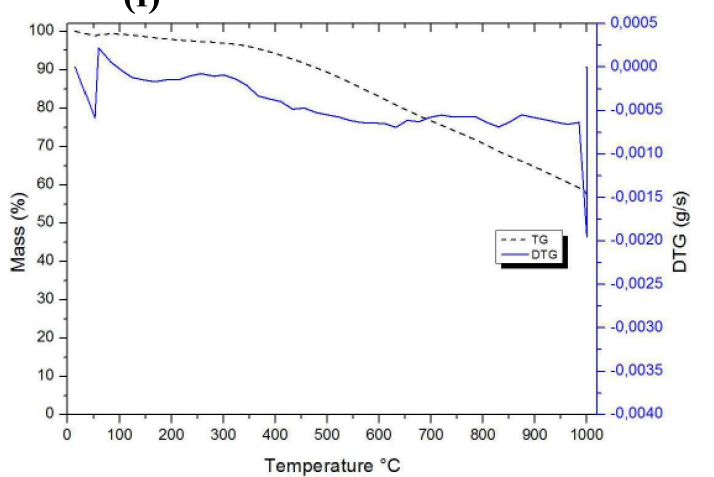

Figure 2 - Thermogravimetric analysis (TG and DTG) of the (a) biomass; (b) biomass ashes generated in the laboratory; (c) readler residues; (d) hopper residues; (e) scrubber residues; (f) decanter residues.

Figura 2 - Análise Termogravimétrica (TG e DTG) das amostras de (a) biomassa florestal; (b) cinzas da biomassa gerada em laboratório; (c) resíduos do readler; (d) resíduo da tremonha; (e) resíduo do lavador; (f) resíduos do decantador.

Table 1 - Stages of the mass loss curves (TG) of residues generated in the boiler, biomass, and biomass ashes generated in the laboratory. Tabela 1 - Estágios das curvas de perda de massa (TG) dos resíduos gerados na caldeira, da biomassa e das cinzas de biomassa geradas

\begin{tabular}{|c|c|c|c|}
\hline Sample & Stage 1 & Stage II & Stage III \\
\hline Biomass & $50^{\circ} \mathrm{C}$ to $150^{\circ} \mathrm{C}$ & $150^{\circ} \mathrm{C}$ to $500^{\circ} \mathrm{C}$ & $500^{\circ} \mathrm{C}$ to $1.000^{\circ} \mathrm{C}$ \\
\hline Biomass ashes & $25^{\circ} \mathrm{C}$ to $90^{\circ} \mathrm{C}$ & - & - \\
\hline Readler residues & $25^{\circ} \mathrm{C}$ to $70^{\circ} \mathrm{C}$ & $70^{\circ} \mathrm{C}$ to $400^{\circ} \mathrm{C}$ & $400^{\circ} \mathrm{C}$ to $1.000^{\circ} \mathrm{C}$ \\
\hline Hopper residues & $100^{\circ} \mathrm{C}$ to $100^{\circ} \mathrm{C}$ & $100^{\circ} \mathrm{C}$ to $400^{\circ} \mathrm{C}$ & $400^{\circ} \mathrm{C}$ to $1.000^{\circ} \mathrm{C}$ \\
\hline Scrubber residues & $25^{\circ} \mathrm{C}$ to $100^{\circ} \mathrm{C}$ & $100^{\circ} \mathrm{C}$ to $420^{\circ} \mathrm{C}$ & $420^{\circ} \mathrm{C}$ to $1.000^{\circ} \mathrm{C}$ \\
\hline Decanter residues & $25^{\circ} \mathrm{C}$ to $90^{\circ} \mathrm{C}$ & $90^{\circ} \mathrm{C}$ to $350^{\circ} \mathrm{C}$ & $350^{\circ} \mathrm{C}$ to $1.000^{\circ} \mathrm{C}$ \\
\hline
\end{tabular}


Table 2 - Energy properties of biomass, biomass ashes and boiler residues at each collection point.

Tabela 2 - Propriedades energéticas da biomassa, das cinzas de biomassa e dos resíduos nos pontos de coleta.

\begin{tabular}{|c|c|c|c|c|c|c|c|}
\hline & Biomass & Biomass ashes & Readler & Hopper & Scrubber & Decanter & $\mathrm{CV}$ \\
\hline $\mathrm{C}(\%)$ & $40.61 \mathrm{~d}$ & $8.60 \mathrm{e}$ & $10.54 \mathrm{e}$ & $98.2 \mathrm{a}$ & $68.45 \mathrm{c}$ & $75.61 \mathrm{~b}$ & 2.48 \\
\hline $\mathrm{H}(\%)$ & $7.84 \mathrm{a}$ & $0.28 \mathrm{~d}$ & $0.73 \mathrm{~d}$ & $3.40 \mathrm{~b}$ & $2.28 \mathrm{c}$ & $1.90 \mathrm{c}$ & 14.74 \\
\hline $\mathrm{S}(\%)$ & $0.98 \mathrm{a}$ & $0.49 \mathrm{~b}$ & $0.19 \mathrm{e}$ & $0.40 \mathrm{c}$ & $0.14 \mathrm{e}$ & $0.24 \mathrm{~d}$ & 8.79 \\
\hline$N(\%)$ & $0.35 \mathrm{a}$ & $0.02 \mathrm{~d}$ & $0.00 \mathrm{~d}$ & $0.20 \mathrm{~b}$ & $0.09 \mathrm{c}$ & $0.23 \mathrm{~b}$ & 8.65 \\
\hline $\begin{array}{c}\text { GCV } \\
(\mathrm{kcal} / \mathrm{kg})\end{array}$ & $4,777 \mathrm{~b}$ & $0.00 \mathrm{e}$ & $823.00 \mathrm{~d}$ & $4,922 \mathrm{~b}$ & $7,180 \mathrm{a}$ & $2,998 \mathrm{c}$ & 5.13 \\
\hline $\mathrm{FCC}(\%)$ & $18.82 \mathrm{~d}$ & $0.33 \mathrm{f}$ & $3.51 \mathrm{e}$ & $63.02 \mathrm{~b}$ & $75.08 \mathrm{a}$ & $29.36 \mathrm{c}$ & 3.39 \\
\hline VC (\%) & $80.22 \mathrm{a}$ & $0.70 \mathrm{e}$ & $18.31 \mathrm{~d}$ & $24.70 \mathrm{~b}$ & $21.20 \mathrm{c}$ & $17.19 \mathrm{~d}$ & 5.78 \\
\hline $\mathrm{AC}(\%)$ & $0.96 \mathrm{e}$ & $98.79 \mathrm{a}$ & $78.18 \mathrm{~b}$ & $12.27 \mathrm{~d}$ & $3.72 \mathrm{e}$ & $53.44 \mathrm{c}$ & 3.82 \\
\hline
\end{tabular}

Note: Means followed by the same letter in the row are statistically equal second Scott Knott Test, a probability level of $95 \%$. C $=$ elemental carbon; $\mathrm{H}=$ elemental hydrogen; $\mathrm{S}=$ elemental surfur; $\mathrm{N}=$ elemental nitrogen; $\mathrm{GCV}=$ gross calorific value; $\mathrm{FCC}=$ fixed carbon content; $\mathrm{VC}=$ volatiles content; $\mathrm{AC}=$ ash content; $\mathrm{CV}=$ coefficient of variation.

and the water-soluble extractives has occurred, losing less than $5 \%$ of the biomass' mass. Stage II is the one when the volatilization and burning of the volatiles (temperatures between $150^{\circ} \mathrm{C}$ to $500^{\circ} \mathrm{C}$ ) happen, with a $70 \%$ mass loss. At Stage II there were polyose and cellulose losses, and a considerable lignin loss, confirmed by the great mass reduction at this stage.

During the thermal analysis, the pyrolysis of the polyoses has occurred at $220-315^{\circ} \mathrm{C}$ and the cellulose's pyrolysis at $315-400^{\circ} \mathrm{C}$. The lignin's mass loss has occurred between 160 and $900^{\circ} \mathrm{C}$ (Yang et al., 2007). In an experiment performed by Giudicianni et al. (2013), the thermogravimetric differential curves (DTG) have shown that lignin is less stable than cellulose and it decomposes at $196^{\circ} \mathrm{C}$, while cellulose degradation begins at about $327^{\circ} \mathrm{C}$. Cellulose degradation occurs in a narrow temperature range. In contrast, lignin pyrolysis is distributed over a wider temperature range (Yang et al., 2007; Giudicianni et al., 2013).

The passive pyrolysis with the consumption of fixed carbon until mass stabilization has occurred in temperatures between $500^{\circ} \mathrm{C}$ and $1000^{\circ} \mathrm{C}$ (Stage III). In Stage III, the mass loss was $99 \%$ of the total mass of the sample with the temperature up to $1000^{\circ} \mathrm{C}$ (Table 1 ). The mass loss that was shown by the TG curve in Stage II (70\%), which represents the combustion of the volatile compounds, was lower than the volatile content obtained from the proximate analysis (80.20\%) (Table 2). Likewise, the fixed carbon content was $18.82 \%$, but the mass remaining after $500^{\circ} \mathrm{C}$, which corresponds to the fixed carbon's burning phase, was around $30 \%$. This difference was due to the residual lignin which continues its degradation process at temperatures between $500^{\circ} \mathrm{C}$ and $900^{\circ} \mathrm{C}$.
The biomass's mass loss rate curve (DTG) showed three peaks of increase in speed. The first was in Stage I (near $100^{\circ} \mathrm{C}$ ), during the drying phase. The other two were in Stage II, one in the beginning $\left(250^{\circ} \mathrm{C}\right)$, when the oxidation and release of volatile compounds, degradation of polyoses and cellulose, and the beginning of the lignin degradation occur. Another one at the end $\left(400\right.$ to $\left.450^{\circ} \mathrm{C}\right)$, when the burning of the volatile compounds, the decomposition, and alteration of the lignin are occurring more significant.

Brand et al. (2018) have carried out the thermogravimetric analysis on Pinus pellets whose residues have the same origin of the biomass analyzed in this work. The TG and DTG curves of the Pinus pellets showed that there was no significant mass loss until the temperature reached approximately. This is due to the drying of the pellets which were tested with an $8 \%$ moisture content. After $200^{\circ} \mathrm{C}$, a slight mass loss occurred while the temperature went up to $380^{\circ} \mathrm{C}$, followed by a rapid mass loss between $380^{\circ} \mathrm{C}$ and $450^{\circ} \mathrm{C}$. The mass loss was attenuated between $450^{\circ} \mathrm{C}$ and $500^{\circ} \mathrm{C}$. The sample mass decreased at a constant rate after $500^{\circ} \mathrm{C}$, and from $500^{\circ} \mathrm{C}$ to $1000^{\circ} \mathrm{C}$, its complete degradation occurred. Therefore, in both studies, pine biomass shows similar thermal degradation behaviors.

As expected, the ash behavior of the calcined biomass (Figure 2 (b)) showed a little mass loss until $100^{\circ} \mathrm{C}$, with subsequent mass stabilization until the final temperature. The thermogravimetric analysis only confirms the ultimate chemical composition of the sample (Table 2). The thermogravimetric and energetic analyses of the ashes of the biomass calcined in the laboratory, under controlled conditions until complete combustion, still count for proving that

Revista Árvore 2019;43(1):e430108 
the residues produced in different parts of the boiler (hopper, scrubber, and decanter) have residual carbon that has energy potential to be used in the combustion system itself or for off-site energy uses.

Figure 2 (c) shows the thermal degradation of the readler residues. First, there was a mass loss by drying until $60^{\circ} \mathrm{C}$, and a high mass loss rate at this temperature. Then, from $60^{\circ} \mathrm{C}$ to $300^{\circ} \mathrm{C}$ (Stages I and II) the mass loss was slower, less than $2 \%$. After that, from $300^{\circ} \mathrm{C}$ to $400^{\circ} \mathrm{C}$, there was an abrupt mass loss of $10 \%$ of the total mass of the sample, switching to a constant and decreasing mass loss rate (DTG) until $850^{\circ} \mathrm{C}$. Finally, the sample reached complete degradation and it maintained near $80 \%$ of the mass after the test had finished. The remaining mass corresponds to the inorganic compounds that are not burned in the process (ash content), which equals the ash content of the readler residues shown in Table 2 .

As for the rate of mass loss, there were four peaks. One below $100^{\circ} \mathrm{C}$, which is equivalent to the moisture content loss. The second one between 100 and $200^{\circ} \mathrm{C}$, corresponding to the emission of volatiles. The third and more accentuated one near $400^{\circ} \mathrm{C}$, due to the burning of the volatiles. And the fourth one, also near $400^{\circ} \mathrm{C}$ and related to the burning of the volatiles.

Readler residues have low energetic potential, as shown by the TGA curves and the analyses of the energy properties (Table 2), due to their high ash content, low levels of elemental carbon, fixed carbon, and gross calorific value. This is an indication that, at this point of the boiler, the grade's cleaning system is being efficient because it's removing the inorganic compounds present in the biomass in a greater proportion without carbon loss, which would represent a loss of energy potential.

The sample of hopper residues showed the first peak of increase of the mass loss rate close to $60^{\circ} \mathrm{C}$, and the second one near $200^{\circ} \mathrm{C}$. From $200^{\circ} \mathrm{C}$ on, both the mass loss and the mass loss rate decreased until the temperature reached $350^{\circ} \mathrm{C}$. After that, both of them kept increasing until $650^{\circ} \mathrm{C}$, the temperature in which the mass loss continued to increase progressively, but with a reduced mass loss rate. This is because the pyrolysis of the material occurs in this stage, remaining constant till $900^{\circ} \mathrm{C}$. Up to $1000^{\circ} \mathrm{C}$, there was an increase in the mass loss rate. Between $350^{\circ} \mathrm{C}$ and $1000^{\circ} \mathrm{C}$ there was a $60 \%$ mass loss, and after the end of the test, only $15 \%$ of the mass remained. These results were close to the proximate analysis of the same sample (Table 2).

The behavior of the scrubber residues was the closest to the hopper ones. The proximate chemical composition of both of them showed the highest fixed carbon content, lower volatile contents and lower ash contents than the other analyzed residues. As the scrubber residues showed higher fixed carbon and lower volatile contents than the hopper residues, the mass loss rate peaks were less marked. The ash content of this sample was $3.72 \%$ (Table 2). However, at the end of the TGA, there was still $30 \%$ of the sample mass remaining, which indicates that temperatures above $1000^{\circ} \mathrm{C}$ are required for its complete degradation. This information is also critical if you wish to reuse the residual carbon of the scrubber residues.

Both hopper and scrubber residues presented a proximate chemical composition similar to the eucalyptus charcoal and the unidentified charcoal samples. However, scrubber residues showed higher gross calorific value, higher fixed carbon content and lower ash content. Masiá et al. (2007), Saidur et al. (2011), Soares et al. (2014), and Pelanda et al. (2015) have evaluated the biomass quality for boiler use, as well as the quality of eucalyptus charcoal and unidentified charcoal samples (Table 3). Comparing their results with the ones obtained in this study, it is possible to verify the proximity of values between the charcoal and the scrubber residues.

The energetic properties and the thermogravimetric analysis indicate that both hopper and scrubber residues have high residual carbon content present in the sample. In addition, the ash contents of the of both samples were $12.27 \%$ and $3.72 \%$, respectively, which represent a small number of residues to be reused in reheat systems where applicable.

According to Demirbas (2005), high levels of residual carbon in the ash indicate a low efficiency of the combustion process. The author claims that the fly ashes could be re-burned to remove the residual carbon, but the fluidized bed boilers would be the most suitable for this purpose as they are more flexible in terms of fuel and they also produce well-burned ash. Duan et al. (2012) supplemented that longer residence times in the ash re-burning system also influence the burning efficiency of the waste's residual carbon. 
Table 3 - Energy properties of different biomass types and charcoal.

Tabela 3 - Propriedades energéticas de diferentes tipos de biomassa e do carvão vegetal.

\begin{tabular}{|c|c|c|c|c|c|}
\hline \multirow[t]{2}{*}{ Properties } & \multicolumn{5}{|c|}{ Biomass types } \\
\hline & Pinus chips & Biomass mix & $\begin{array}{c}\text { Pinus prunning } \\
\text { branches }\end{array}$ & Pinus sawdust & Charcoal \\
\hline $\mathrm{C}(\%)$ & $49.66^{(1)}$ & $49.59^{(1)}$ & $51.90^{(2)}$ & - & $81.60^{(3)}$ \\
\hline $\mathrm{H}(\%)$ & $5.67^{(1)}$ & $5.79^{(1)}$ & $6.30^{(2)}$ & - & $3.29^{(3)}$ \\
\hline S (\%) & $0.08^{(1)}$ & $0.74^{(1)}$ & $0.01^{(2)}$ & - & $0.04^{(3)}$ \\
\hline $\mathrm{N}(\%)$ & $0.51^{(1)}$ & $2.43^{(1)}$ & $0.50^{(2)}$ & - & $0.22^{(3)}$ \\
\hline GCV (kcal/kg) & - & - & - & $4,821^{(4)}$ & $7,609^{(4)}$ \\
\hline FCC (\%) & $21.65^{(1)}$ & $18.14^{(1)}$ & $15.10^{(2)}$ & $17.85^{(4)}$ & $74.27^{(4)}$ \\
\hline $\mathrm{VC}(\%)$ & $72.40^{(1)}$ & $69.36^{(1)}$ & $82.20^{(2)}$ & $79.45^{(4)}$ & $24.52^{(4)}$ \\
\hline $\mathrm{AC}(\%)$ & $5.95^{(1)}$ & $12.49^{(1)}$ & $2.70^{(2)}$ & $2.44^{(4)}$ & $1.21^{(4)}$ \\
\hline
\end{tabular}

Source: 1 = Masiá et al., 2007; 2 = Saidur et al., 2011; 3 = Carvalho Soares et al., 2014; 4 = Pelanda et al. (2015).

Note: $\mathrm{C}=$ elemental carbon; $\mathrm{H}=$ elemental hydrogen; $\mathrm{S}=$ elemental surfur; $\mathrm{N}=$ elemental nitrogen; $\mathrm{GCV}=$ gross calorific value; $\mathrm{FCC}=$ fixed carbon content; $\mathrm{VC}=$ volatiles content; $\mathrm{AC}=$ ash content.

Therefore, if the residual carbon of the hopper and the scrubber residues are applied to reinjection systems in the boiler itself or burned in another equipment to generate energy, their combustion will be slower than the biomass one, requiring a residence time in the furnace longer than for the burning of in natura biomass. This aspect shows that these two materials can't be mixed for co-firing without making adjustments in the furnace and in the parameters of the boiler's operation system.

Finally, the decanter residues lost $55 \%$ of their mass and $45 \%$ remained in the form of ash after the burning process. These results are compatible with the high ash content showed by the proximate analysis. As the volatile and fixed carbon contents were closer to each other, the mass loss curve was smooth and continuous. There were only two peaks of higher loss rate, one below $100^{\circ} \mathrm{C}$, related to the moisture loss, and one at the end, during the reading stabilization of the remaining ash content. Although the elemental carbon content was high, the amount of residual carbon, which is available for energy generation, was low. This fact, coupled with the high ash content $(53.44 \%)$ and the low calorific value, makes the reuse of decanter residues less attractive for combustion.

\section{CONCLUSIONS}

The chemical and energetic properties of the biomass and the residues produced during the combustion process, as well as their thermal degradation behavior, are different among the collection points, which demonstrates that the combustion process is dynamic and varies within the boiler system.

The chemical composition and the thermal degradation behavior recorded in the readler residues indicate that there is a high combustion efficiency of the biomass in the boiler's furnace.

The hopper and scrubber's light residues (fly ashes) presented chemical and energetic properties, and, thermal behavior similar to the eucalyptus charcoal. However, in order to reuse these residues in reinjection or reheat systems, adjustments in combustion facilities are essential to both achieve combustion efficiency and avoid operational problems.

The decanter residues do not have the potential for energy reuse.

\section{REFERENCES}

Abbasi T, Abbasi SA. Biomass energy and the environmental impacts associated with its production and utilization. Renewable and Sustainable Energy Reviews. 2010;14(3): 919-37.

American Society for Testing and Materials ASTM. ASTM D 1762-84: Standard Test Method for Chemical Analysis of Wood Charcoal. 2013. 2p.

Barneto AG, Carmona JA, Conesa JA. Effects of the composting and the heating rate on biomass gasification. Energy \& Fuels. 2008;23(2):951-7.

Brand MA, Barnasky RRDS, Carvalho CA, Buss R, Waltrick DB, Jacinto RC. Thermogravimetric

\section{Revista Árvore 2019;43(1):e430108}


analysis for characterization of the pellets produced with different forest and agricultural residues.

Ciência Rural. 2018;48(11):1-11.

Brand MA. Energia de biomassa florestal. Interciência; 2010.

Soares VC, Bianchi ML, Trugilho PF, Júnior Pereira A, Höfler J. Correlações entre as propriedades da madeira e do carvão vegetal de híbridos de eucalipto. Revista Árvore. 2014;38(3):543-9.

Demirbas A. Potential applications of renewable energy sources, biomass combustion problems in boiler power systems and combustion related environmental issues. Progress in Energy and Combustion Science. 2005;31(2):171-92.

Deutsches Institut Für Normung. DIN 51900: Testing of Solid and Liquid Fuels. Determining the Gross Calorific Value of Solid and Liquid Fuels Using the Bomb Calorimeter, and Calculation of Net Calorific Value e Part 1-3. Germany: 2003.

Duan L, Liu D, Chen X, Zhao C. Fly ash recirculation by bottom feeding on a circulating fluidized bed boiler co-burning coal sludge and coal. Applied Energy. 2012;95:295-9.

Félix CRDO, Azevedo Júnior AFD, Freitas CC, Pires CADM, Teixeira V, Frety R, et al. Pirólise rápida de biomassa de eucalipto na presença de catalisador AlMCM-41. Matéria. 2017;22:1-11.

Garba MU, Ingham DB, Ma L, Degereji MU, Pourkashanian M, Williams A. Modelling of deposit formation and sintering for the co-combustion of coal with biomass. Fuel. 2013;113:863-72.

Giudicianni P, Cardone G, Ragucci R. Cellulose, hemicellulose and lignin slow steam pyrolysis: Thermal decomposition of biomass components mixtures. Journal of Analytical and Applied Pyrolysis. 2013;100:213-22.

Hupa M, Karlström O, Vainio E. Biomass combustion technology development-It is all about chemical details. Proceedings of the Combustion Institute. 2017;36(1):113-34.

James AK, Thring RW, Helle S, Ghuman HS. Ash management review-applications of biomass bottom ash. Energies. 2012;5(10):3856-73.

Masiá AT, Buhre BJP, Gupta RP, Wall TF. Characterizing ash of biomass and waste. Fuel Processing Technology. 2007;88(11-12):1071-81.

Mothé CG, Azevedo AD. Análise térmica de materiais. São Paulo: 2002. p.113-5.

Nyakuma BB, Ahmad A, Johari A, Abdullah TAT. Thermogravimetric and kinetic analyses of Oil Palm Empty Fruit Bunch (OPEFB) Pellets Using the Distributed Activation Energy Model. Journal of Physical Science. 2016;27(3):67-83.

Pelanda KA, Potulski DC, Silva DA, Ferraz FA. Avaliação das possíveis implicações do uso de diferentes biomassas florestais como biocombustível em geradores de vapor. Ciência da Madeira.2015;6(2):112-21.

Saidur R, Abdelaziz EA, Demirbas A, Hossain MS, Mekhilef S. A review on biomass as a fuel for boilers. Renewable and Sustainable Energy Reviews. 2011:15(5):2262-89.

Sarenbo S. Wood ash dilemma-reduced quality due to poor combustion performance. Biomass and Bioenergy. 2009;33(9):1212-20.

Yang H, Yan R, Chen H, Lee DH, Zheng C.

Characteristics of hemicellulose, cellulose and lignin pyrolysis. Fuel. 2007;86(12-13):1781-8. 